\title{
20th World Congress of the International Society on Toxinologyに 参加して
}

\author{
（2019年11月26日受理）
}

2019年9月8日から 13 日にわたり “20th World Congress of the International Society on Toxinology (IST2019, 国際毒 素学会議)”がアルゼンチンの首都：ブエノスアイレスにて開 催された.アルゼンチンは南米において, ブラジルに次ぐ領 土面積を誇る国家である.この国は，かつてスペインの植民 地であったという歴史をもち, スペイン文化が色濃く受け継 がれていることから, “南米のヨーロッパ”と称されている. 中心街に位置する官公庁や劇場など重要建造物の周辺はヨー ロッパ風の古き町並みが残され，路地ではタンゴのストリー トショーもしばしば行われていた. 今回の会場である Hotel Panamericanoは, “7月9日通り”という世界で最も広いとさ れる大通り沿いに建っており，すぐ近くにはブエノスアイ レス創設 400 周年を記念して建てられた巨塔：Obeliscoが㪘 え立っていた (写真1). 本会議を主催する国際毒素学会は, 毒素学専門学術誌 “Toxicon”を発行していることで知られて おり，2年ごとにアジア，アメリカ，ヨーロッパ各大陸持ち 回りで開催されている。この国際会議では, へビ, クモ, サ ソリ，微生物あるいは植物などバラエティーに富んだ生物毒 を扱う研究者たちが議論を交わす．筆者は海外渡航経験がそ しく, そのうえ海外で開催される学会への参加・発表は初め ての経験で, そのうえ, 南米の治安が良くないという情報に 過敏になっていた. 南半球に位置するアルゼンチンの季節が 日本と真逆であることに, 出発 1 週間前になってからようや く気づくなど不安が山積みであった。 また, 日本から地球の 裏側まで行くだけあり, 渡航時間も長く (片道30時間), 現 地時間9月 8 日の夜中にホテルに到着するや否や気絶するよ うに眠りについた。 そして翌日の9月9日から国際毒素学会 議が開催された(写真2).

本大会では Public Health Issues, Basic Toxinology, Clinical Toxinology, Toxinological Technologiesの 4 種のトピックで, 約 60 題のオーラルプレゼンテーションと, 約 160 題のポス タープレゼンテーションが行われた。発表内容は多岐にわた

\footnotetext{
\# IST 2019 (Yusuke Yosнiмото)

(C) 日本農薬学会
}

り, 筆者と同じ生物毒由来の生理活性ペプチドの同定研究以 外に, 抗へビ毒タンパク質のメカニズム解明に関する発表も あった，あるいは，生育環境が成長ステージで異なると言わ れているが, その環境の変化によって毒を獲得する生物の化 学生態学的な研究などもあって, 生物毒の種類・研究背景・ 手法に関して多岐にわたるものであった。

筆者は“Characterization of Insecticidal Peptides from the Venom of the North African Scorpion, Buthacus leptochelys" というタイトルでポスター発表を行った. エジプトの共同研 究者から譲り受けた北アフリカに生息するサソリ：Buthacus leptochelysの毒液に含まれる新規生理活性ペプチドを, 殺虫 活性試験を指標としながら単離し, 質量分析を駆使して極微 量のサンプル（1 mg未満）から構造決定を達成したという 報告を行った (写真3). 筆者の研究グループでは, 十数年 にわたり日本に生息するサソリ（Liocheles australasiae：ヤ エヤマサソリ）などの毒液由来の新規生理活性ペプチドの探 索・構造決定・合成・活性評価研究を行ってきた，筆者ら は質量分析を主軸とした超微量成分の分析を強みとしてい るが, 近年, トランスクリプトーム解析が普及したことによ り，“mRNAの情報”と“質量分析による部分的な配列情報” を組み合わせることでペプチドやタンパク質を短時間かつ網 羅的に同定できる. 生物毒由来の生理活性ペプチドの同定研 究においても, 短時間でかつ網羅的にペプチドを同定するこ とが盛んに行われている. 本ポスターセッションでもその技 術を活用し膨大な量のペプチドの同定を達成した研究例がし ばしば見られた、筆者らが今回取り組んだ研究では, 遺伝資 源の獲得が困難であるため, 全アミノ酸配列情報を質量分析 で網羅することにより決定する “de novo sequencing法”を用 いている.この手法は比較的古典的であり, トランスクリプ トーム解析を用いるとブラックボックスになりがちなため, MS/MS解析研究に興味を示してくださる研究者の方々がし ばしば見受けられた．特に年配の方々には懐かしく感じられ るのか, 大変興味深く聞いてくださった. もちろん筆者らも 短時間でかつ網羅的にペプチドやタンパク質を同定すること が可能であるトランスクリプトーム解析の有用性は十分理解 

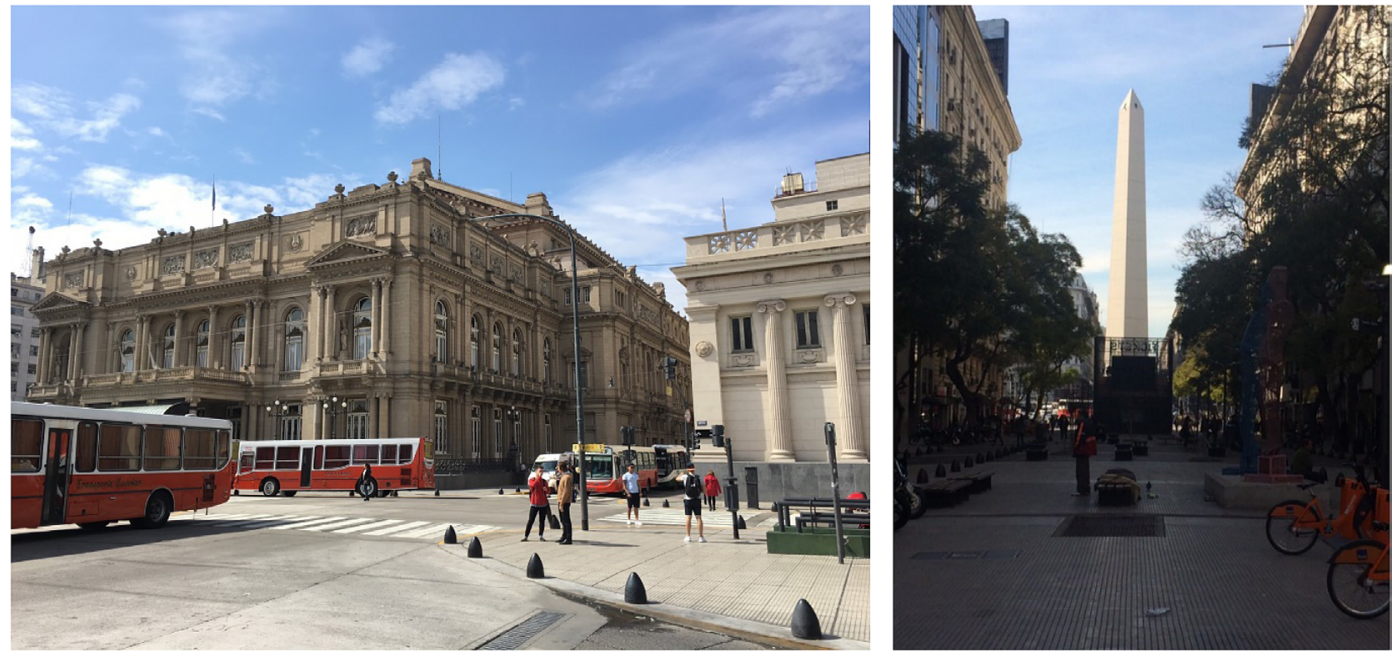

写真 1. ブエノスアイレス中心街の様子（左）, 会場ホテルの傍に算え立つ巨塔： Obelisco（右).

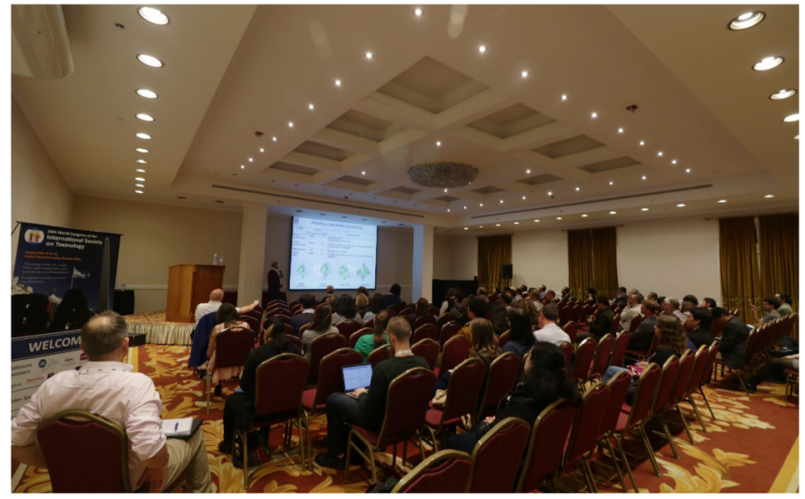

写真2. オーラルプレゼンテーション会場の様子.

しているが，これらは既知のものと相同性があるものしか発 見できないという問題点も抱えている．また，本研究のよう に遺伝資源の確保が困難な場合では, やはりこのような古典 的な手法に頼るほかないのが現状である. したがって, 近年 はしばしばこのような古典的な手法も見直されてきており， 筆者自身も今後は先進的な手法と古典的な手法を上手に組み 合わせることも重要であると考え，それらを伝えられるよう 心掛けてポスタープレゼンテーションに臨んだ.

今回の学会では, 昼食休悡に筆者らの共同研究者である Leuven大学 (ベルギー) の方々と食事したり, 学生主体の 懇親会にも参加したりし，積極的に海外の研究者や学生と ディスカッションを行い，お互いの国の文化についても雑談 を交わした．特に学生のみの懇親会では筆者以外に日本人は いなかったことから英語で会話し続けなければならないとい うハードな状況であった．最初は戸惑ったが，一度話してみ ると自身が思っていた以上に会話がはずみ，有意義な時間を 過ごすことができた．な扔，余談であるが，その懇親会で筆 者に話しかけてくれた外国人学生のほとんどが, 日本のアニ メーションに大変興味を持っていて, 中には日本語を少し話

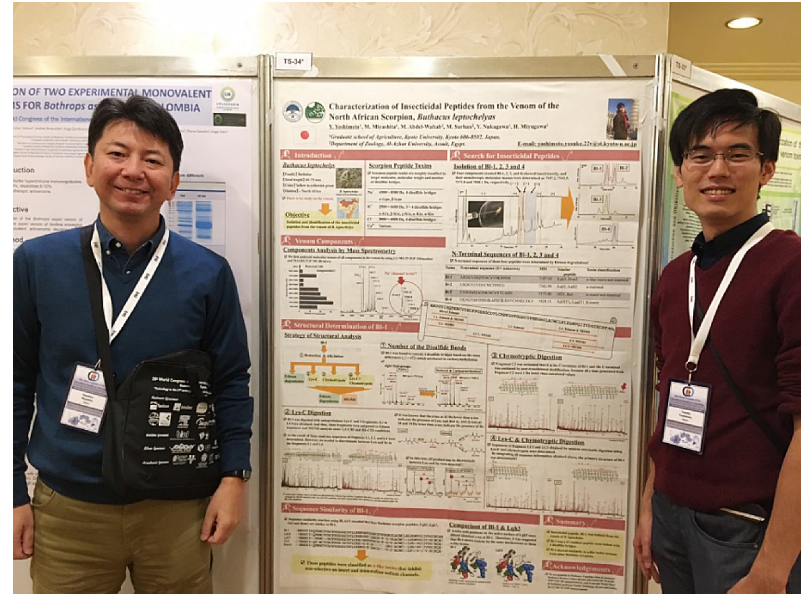

写真3. ポスターの前にて, 宮下正弘准教授 (左) と筆者 (右).

せる学生まで見受けられた。 日本を代表する文化であるアニ メーションが地球の裏側まで届いて評価されていることに感 動を覚えた。

滞在最終日, 飛行機が出発するまでの間, ブエノスアイレ ス市内を散策した。中でも“レコレータ墓地”が最も印象深 かった。この墓地は 1882 年に開設され, 歴代大統領や由緒 正しき一族, あるいは歴史上の偉人などが様々な伝統的建築 法を用いて建てられた納骨堂に埋葬されていて, 墓地とは思 えぬほど美しい場所であった (写真4).

本学会に参加し, 筆者は海外の研究者の視点から自身の研 究はどのように見えているのか理解することができただけで なく, お互いの文化の違いや研究思考などに触れるなど大変 貴重な経験を積むこともできた。 また, 本学会を通して海外 の研究者を相手に発表することの難しさを痛感した。もちろ 几筆者の英語力が至らない点もあるが, それ以上に海外の研 究者のポスターやスライドはより簡潔に見やすく作製されて いること, 実験データの見せ方, そしてプレゼン手法にも工 

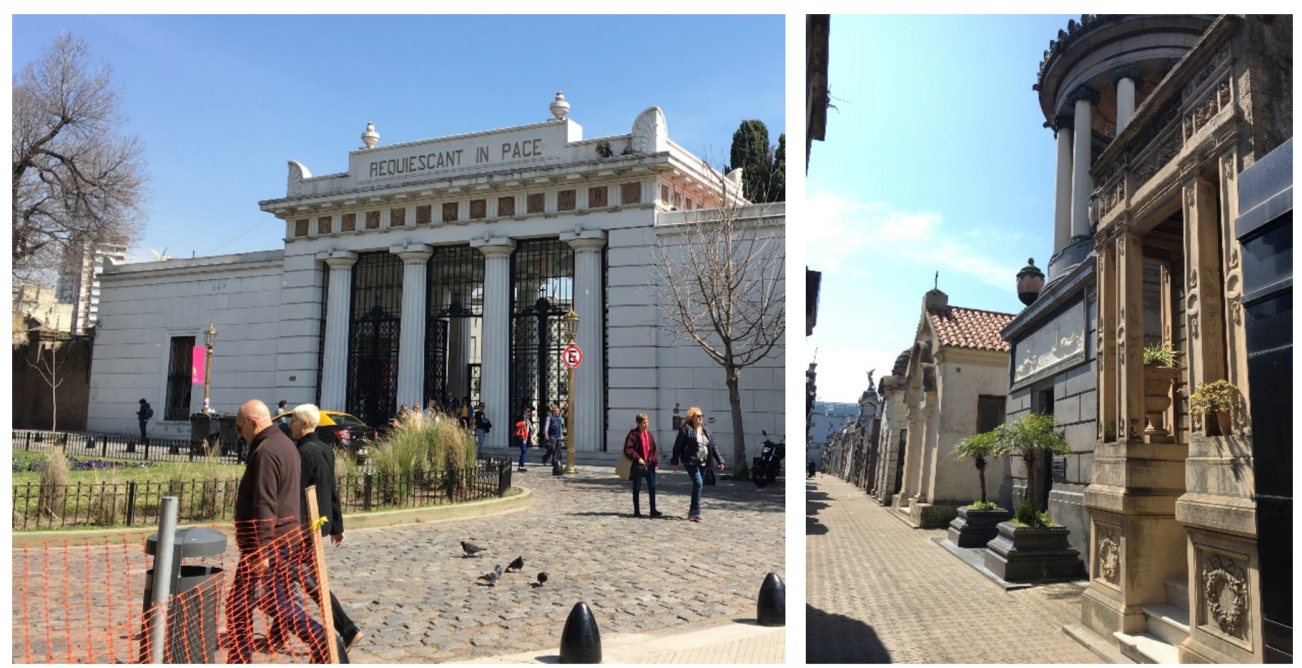

写真4. 滞在最終日に訪れたレコレータ墓地入り口（左）と内部（右). 右の写真における建造物 1 軒 1 軒が納骨堂になっている.

夫が凝らされていた．筆者の今後のプレゼンテーションにも 取り入れたいと考える部分が多かった。最後になりますが, 今回日本農薬学会より海外渡航費の援助を賜り, 筆者の研究 者人生において大変貴重な経験, そして将来を考えるよい機
会を与えていただいたこと心より深謝申し上げます。

(京都大学大学院農学研究科 義本裕介) 